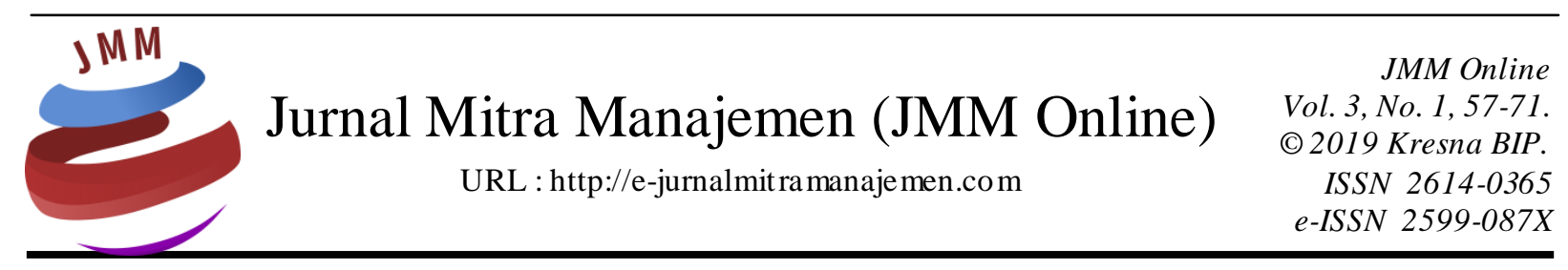

\title{
PENGARUH STORE ATMOSPHERE TERHADAP MINAT BELI KONSUMEN PADA SEJIWA COFFEE
}

\author{
Dian Pertiwi Wulandari ${ }^{1)}$, Maya Ariyanti ${ }^{2)}$ \\ Universitas Telkom
}

INFORMASI ARTIKEL

Dikirim : 27 Desember 2018

Revisi pertama : 13 Januari 2019

Diterima : 19 Januari 2019

Tersedia online : 31 Januari 2019

Kata Kunci : Store Atmosphere, Exterior, General Interior, Store Layout, Interior

Display, Minat Beli Konsumen

Email :

dipertland@student.telkomuniversity.ac.id ${ }^{1)}$, letterbox.maya@gmail.com ${ }^{2)}$

\begin{abstract}
ABSTRAK
\end{abstract}
Bisnis kuliner adalah salah satu peluang bisnis yang sedang menjadi trend dan diyakini memiliki prospek bagus ke depan. Dalam rangka memenuhi tuntutan masyarakat akan restaurant, café maupun coffee shop para pelaku usaha dituntut untuk membuat konsep tempat yang nyaman dan dapat membuat pengunjung betah berlama lama. Hal ini didukung juga oleh banyaknya pengguna media sosial Instagram di kalangan millenials. Pengguna media sosial yang semakin banyak pun berpotensi untuk memperkenalkan suatu brand dengan sangat cepat dan hal ini berpengaruh terhadap minat beli konsumen. Penelitian ini bertujuan untuk mengetahui seberapa besar pengaruh store atmosphere terhadap minat beli konsumen pada Sejiwa Coffe. Metode penelitian yang digunakan adalah metode kuantitatif dengan teknik non-probability accidental sampling. Menggunakan 400 responden. Teknik analisis yang digunakan adalah Analisis jalur dengan menggunakan aplikasi SPSS 23.0. Berdasarkan hasil penelitian didapatkan beberapa kesimpulan yang memberikan jawaban terhadap rumusan masalah yaitu tanggapan responden mengenai store atmosphere dan minat beli konsumen pada Sejiwa Coffe terkategori baik. Store atmosphere pada Sejiwa Coffee secara simultan memiliki pengaruh positif dan signifikan terhadap minat beli konsumen sebesar 68,4\% dan store atmosphere pada Sejiwa Coffee secara parsial memiliki pengaruh positif dan signifikan terhadap minat beli konsumen. 


\section{PENDAHULUAN \\ Latar Belakang}

Sejiwa Coffee memiliki rating yang cukup tinggi di situs pergikuliner.com dari skor 5 Sejiwa Coffee mendapatkan poin sebesar 3.9. berdasarkan rating tersebut Sejiwa Coffee paling unggul dalam suasana toko dengan nilai rating 4.3. Keunggulan yang kedua adalah kebersihan hal tersebut menunjukan bahwa kebersihan pada Sejiwa Coffe selalu terjaga dengan baik. (https://pergikuliner.com). Penulis melakukan sebuat riset kecil dengan membagikan kuesioner kepada 30 orang responden. Hal tersebut dilakukan penulis untuk mengetahui berdasarkan store atmosphere yang dimiliki Sejiwa Coffee dan beberapa pesaingnya yaitu Mimiti Coffe \& Space, Cups Coffee \& Kitchen, Contrast Coffee dan Yumaju Coffee mana diantaranya yang paling menarik minat konsumen untuk berkunjung dan bahkan melakukan pembelian. Hasil riset tersebut menghasilkan data bahwa Sejiwa Coffe berada pada tingkat pertama dalam menarik minat konsumen untuk berkunjung dan bahkan melakukan pembelian karena. Diartikan bahwa store atmosphere pada Sejiwa Coffee dapat menarik minat beli konsumen. Meskipun Sejiwa Coffee memiliki store atmosphere yang baik, namun Sejiwa Coffee juga masih mendapatkan keluhan negative dari beberapa pelanggan. Pelanggan berkomentar bahwa lantai 2 pada Sejiwa Coffee terasa agak panas dan bising, karyawan Sejiwa Coffee kurang informatif mengenai produk yang disediakan dan pada saat hujan lantai 2 Sejiwa Coffee juga berisik. Dari keluhan-keluhan pelanggan tersebut masalah yang ditemukan berada pada penerapan sub-variabel General interior dari store atmosphere yang masih kurang baik. Berdasarkan latar belakang diatas maka penulis tertarik untuk meneliti adakah pengaruh store atmosphere terhadap keputusan pembelian konsumen pada Sejiwa Coffee secara simultan maupun parsial, dengan judul "Pengaruh Store Atmosphere terhadap Minat Beli Konsumen pada Sejiwa Coffee”.

\section{Rumusan Masalah}

Berdasarkan latar belakang diatas maka dapat dirumuskan masalah yang akan diteliti sebagai berikut:

1. Bagaimana Store Atmosphere pada Sejiwa Coffee.

2. Bagaimana minat beli konsumen pada Sejiwa Coffee.

3. Apakah terdapat pengaruh simultan Store Atmosphere terhadap Minat beli konsumen pada Sejiwa Coffee.

4. Apakah terdapat pengaruh parsial Store Atmosphere terhadap Minat beli konsumen pada Sejiwa Coffee.

\section{Tujuan Penelitian}

Berdasarkan perumusan masalah penelitian maka tujuan dari penelitian ini adalah :

1. Untuk mengetahui bagaimana Store Atmosphere pada Sejiwa Coffe Bandung.

2. Untuk mengetahui bagaimana minat beli konsumen pada Sejiwa Coffe Bandung.

3. Untuk mengetahui apakah terdapat pengaruh simultan Store Atmosphere terhadap minat beli konsumen pada Sejiwa Coffe. 
4. Untuk mengetahui apakah terdapat pengaruh parsial Store Atmosphere terhadap minat beli konsumen pada Sejiwa Coffe.

\section{KAJIAN PUSTAKA \\ Store Atmosphere}

Menurut Levy \& Weitz (2012) dalam Katarika \& Syahputra (2017), Atmosfer mengacu pada desain lingkungan seperti komunikasi visual, pencahayaan, warna, musik, dan aroma untuk mensimulasikan respon persepsi dan emosi pelanggan dan pada akhirnya mempengaruhi perilaku pembelian mereka.

Menurut Berman \& Evan (2010) dalam Katarika \& Syahputra (2017) Store Atmosphere dapat diartikan bahwa bagi sebuah toko, penting untuk menonjolkan tampilan fisik, suasana toko berguna untuk membangun citra dan menarik minat pelanggan.

\section{Elemen-Elemen Store Atmosphere}

Menurut Berman \& Evan (2010) dalam Katarika \& Syahputra (2017) Store Atmosphere terd iri dari empat elemen, yaitu :

1. Exterior (Bagian Luar Toko).

Sub Elemen Exterior terdiri dari:

a. Storefront (bagian depan toko).

b. Marquee (papan nama toko).

c. Store entrance (pintu masuk toko).

d. Display Windows (tampilan pajangan).

e. Exterior Building Height

f. Surrounding Stores and Area (toko dan area sekitar).

g. Parking Facilities (fasilitas tempat parkir).

2. General Interior (interior umum).

Sub elemen dalam general interior yaitu:

a. flooring (jenis lantai).

b. Colour and Lighting (warna dan pencahayaan).

c. Scent and Sound (aroma dan musik).

d. Store fixtures (peralatan toko).

e. Wall Textures (tekstur dinding).

f. Temperature (suhu udara).

g. Aisless Create (lorong ruang).

h. Dressing facilities (kamar pas).

i. Vertical Transportation (alat transportasi antar lantai).

j. Price Levels and Displays.

k. Store Personel (karyawan toko).

1. Technology (teknologi).

m. Store Cleanliness (kebersihan).

3. Store Layout (tata letak toko).

Sub elemen dari Store Layout yaitu:

a. Allocation of floor space (alokasi ruang lantai).

b. Classification of store offerings (klasifikasi penawaran toko). 
c. Determination of A Traffic-Flow Pattern (penentuan pola lalu lintas aliran).

d. Mapping out In-Store Location.

e. Arrangement Of Individual Products.

4. Interior (Point Of Purchase) Displays.

Sub Elemen dari Interior (Point Of Purchase) Displays adalah:

a. An Assortmen Display, dengan suasana terbuka, konsumen akan senang untuk merasakan, melihat dan mencoba produk.

b. A theme setting display

c. An Ensemble Display

d. A rack and Case Display

e. A Cut Case and Dump Bin.

\section{Minat Beli Konsumen}

Menurut Schiffman dan Kanuk (2012:201) dalam Putra \& Wijaksana (2017) menyatakan bahwa minat merupakan salah satu aspek psikologis yang memiliki pengaruh cukup besar terhadap sikap perilaku. Penilaian konsumen terhadap produk tergantung pada pengetahuannya akan informasi tentang fungsi sebenarnya dari produk tersebut, dengan demikian konsumen yang berminat untuk melakukan pembelian suatu produk dipengaruhi oleh informasi yang diterima. Adapun Indikator-indikator minat beli Menurut Schiffman dan Kanuk (2008:470-471) dalam Putra \& Wijaksana (2017) sebagai berikut:

a. Ketertarikan mencari informasi yang lebih tentang produk.

b. Mempertimbangan untuk membeli

c. Keinginan untuk mengetahui produk

d. Ketertarikan untuk mencoba produk

e. Keinginan untuk memiliki produk

\section{Pengaruh Store Atmos phe re terhadap Minat Beli Konsumen}

Menurut Suhartanto et al. (2017:192) desain toko yang dapat memberikan rasa nyama kepada pelanggan, akan membuat pelanggan menjadi betah dan cenderung membuat mereka menggunakan waktunya untuk berkeliling menikmati suasana toko. Hal ini mengidentifikasikan bahwa desain toko dapat memberi dampak pada perilaku konsumen secara positif dan menguntungkan bagi peritel.

\section{METODE PENELITIAN}

\section{Tempat, Waktu dan Subjek Penelitian}

Tempat penelitian ini dilakukan di Bandung. Waktu penelitian mulai dari bulan September hingga Desember 2018. Objek penelitian ini adalah Sejiwa coffe Bandung yang bergerak pada bidang usaha kuliner berjenis coffee shop.

\section{Jenis Penelitian}

Metode penelitian yang digunakan pada penelitian ini merupakan metode kuantitatif dengan jenis deskriptif dan kausal. Jenis data yang digunakan berdasarkan waktu penelitian menggunkan data cross-section. 


\section{Teknik Pengumpulan Data}

Teknik pengumpulan data menggunakan penyebaran kuesioner yang disebarkan kepada 400 responden dan studi kepustakaan. Populasi penelitian ini adalah pengunjung Sejiwa Coffee yang tidak diketahui jumlahnya pastinya.

\section{Teknik Analisis Data}

Teknik analisis data yang digunakan adalah analisis deskriptif dan path analysis. Analisis deskriptif digunakan untuk menjawab pertanyaan penelitian mengenai bagaimana store atmosphere dan minat beli konsumen pada Sejiwa Coffee. Sedangkan path analysis digunakan untuk menjawab pertanyaan penelitian mengenai seberapa besar pengaruh store atmosphere terhadap minat beli konsumen secara parsial.

Dalam penelitian pernyataan kuesioner mengenai Store Atmosphere menggunakan 32 item, salah satu pernyataannya adalah "Saya merasa bagian depan Sejiwa Coffee mencerminkan keunikan yang sesuai dengan citra cafe". Sementara untuk pernyataan Minat Beli Konsumen menggunakan 5 item, salah satu pernyatannya adalah "Saya ingin memiliki pengalaman mencoba produk Sejiwa Coffee". Skala yang digunakan terdiri dari 5 skala likert. Untuk pernyataan Store Atmosphere dan Minat Beli Konsumen skala tersebut terdiri dari sangat tidak setuju (1), tidak setuju (2), ragu-ragu (3), setuju (4), sangat setuju (5). Pada penelitian ini menggunakan uji reliabilitas dengan menggunakan Cronbach's Alpha dengan nilai yang dihasilkan untuk variabel Store Atmosphere (X) sebesar 0,934 dan variabel Minat Beli Konsumen (Y) sebesar 0,924. Dalam proses pengolahan data penulis menggunakan IBM SPSS 23.

Tabel 1. Aspek Demografi

\begin{tabular}{llll}
\hline $\begin{array}{c}\text { Faktor } \\
\text { Demografi }\end{array}$ & \multicolumn{1}{c}{ Klasifikasi } & $\begin{array}{c}\text { Jumlah } \\
\text { Responden }\end{array}$ & $\%$ \\
\hline Jenis Kelamin & Pria & 175 & $44 \%$ \\
& Wanita & 225 & $56 \%$ \\
\hline Usia & $<$ 18 Tahun & 51 & $12 \%$ \\
& 18-22 Tahun & 227 & $57 \%$ \\
& Tahun & 87 & $22 \%$ \\
& $>$ 27 tahun & 35 & $9 \% \mathrm{P}$ \\
\hline Pekerjaan & Pelajar/Mahasis wa & 256 & $62 \%$ \\
& Pegawai Negeri/Swasta & 90 & $23 \%$ \\
& Wirausaha & 41 & $10 \%$ \\
& Lain-lain & 22 & $5 \%$ \\
\hline Pendapatam & $<$ Rp 999.999 & 67 & $17 \%$ \\
& Rp 1.000.000 & 170 & $42 \%$ \\
& 2.999.999 & 81 & $20 \%$ \\
& Rp 3.000.000 - Rp 5.000.00 & 82 & $21 \%$ \\
& $>$ Rp 5.000.000 & & \\
\hline
\end{tabular}

Sumber : Hasil Penelitian, diolah (2018)

Berdasarkan hasil penelitian ini terlihat bahwa sebagian besar responden berjenis kelamin wanita yaitu sejumlah 225 responden dengan persentase sebesar $56 \%$ dari total 400 responden dan untuk laki- laki sejumlah 175 responden dengan persentase 44\%.Hal tersebut menunjukan bahwa responden yang mengetahui Sejiwa Coffee 
didominasi oleh pengunjung wanita dan dalam memilih tempat makan wanita lebih tertarik untuk datang ke toko yang memiliki store atmosphere menarik dibandingkan dengan laki-laki. Dari segi Usia responden yang berusia 18-22 tahun sejumlah 227 dari 400 responden dengan persentase 575\%. Kemudian 23-27 tahun sejumlah 87 responden dengan persentase $22 \%$. Lalu $<18$ tahun sejumlah 51 responden dengan persentase $12 \%$ dan yang terakhir $>27$ tahun sejumlah 35 responden dengan persentase $9 \%$. Karakteristik tersebut menunjukan bahwa responden yang mengetahui Sejiwa Coffee didominasi oleh kalangan muda. Dari segi pekerjaan sebagian besar responden berstatus sebagai pelajar/mahasiswa yaitu berjumlah 256 dari 400 responden dengan persentase $62 \%$, kemudian Pegawai Negeri/Swasta berjumlah 90 responden dengan persentase $23 \%$, lalu Wiraswasta berjumlah 41 responden dengan persentase $10 \%$ dan yang terakhir yaitu lain lain (pensiun, enterneiner, artist, dll) berjumlah 22 responden dengan persentase 5\%. Sesuai dengan target Sejiwa Coffe yaitu kalangan mahasiswa, responden yang mengetahui Sejiwa Coffee di dominasi oleh para pelajar/mahasiswa dan yang terakhir dari segi pendapatan menunjukan bahwa sebagian besar responden berpendapatan sekitar Rp 1.000.000 - Rp 2.999.999 perbulan dengan julah responden sebanyak 170 dari 400 responden dengan persentase 42\%. kemudian > Rp 5.000.000 dengan jumlah 82 responden dengan persentase 21\%, lalu Rp 3.000.000 - Rp5.000.000 dengan jumlah 81 responden dengan persentase $20 \%$ dan yang terakhir yaitu $<999.999$ dengan jumlah 67 responden dengan persentase $17 \%$. Hal tersebut sudah sesuai dengan target Sejiwa Coffe yaitu kalangan menengah ke atas, responden yang mengetahui Sejiwa Coffee di dominasi oleh kalangan menengah keatas.

\section{HASIL PENELITIAN DAN PEMBAHASAN Hasil Penelitian Analisis Deskriptif}

Dalam perhitungan aspek Exterior menunjukkan nilai yang diperoleh 12478 atau $78,0 \%$ dari skor ideal yaitu 16000. Dengan demikian tanggapan responden mengenai eksterior memiliki kategori yang baik. Dari aspek General Interior menunjukkan nilai yang diperoleh 21547 atau 82,9\% dari skor ideal yaitu 26000. Dengan demikian tanggapan responden mengenai general interior memiliki kategori yang baik. Dari aspek Store Layout menunjukkan nilai yang diperoleh 9521 atau 79,3\% dari skor ideal yaitu 12000. Dengan demikian tanggapan responden mengenai store layout memiliki kategori yang baik. Dari aspek Interior Display menunjukkan nilai yang diperoleh 8068 atau 80,7\% dari skor ideal yaitu 10000. Dengan demikian tanggapan responden mengenai Interior Display memiliki kategori yang baik. Secara Keseluruhan Store Atmosphere menunjukkan nilai yang diperoleh 51614 atau 80,6\% dari skor ideal yaitu 64000. Dengan demikian tanggapan responden mengenai Store Atmosphere memiliki kategori yang baik. Begitupun dengan Minat Beli Konsumen pada Sejiwa Coffee menunjukkan nilai yang diperoleh 7725 atau 77,3\% dari skor ideal yaitu 10000. Dengan demikian tanggapan responden mengenai eksterior memiliki kategori yang baik. 


\section{Analisis Jalur}

Berikut merupakan hasil perhitungan koefisien jalur berdasarkan output SPSS.

Tabel 2. Besaran Koefisien Jalur pada SPSS

\begin{tabular}{|c|c|c|}
\hline Variabel & Koefisien Jalur & Total Pengaruh $\left(\mathbf{R}^{2}\right)$ \\
\hline Exterior $\left(\mathrm{X}_{1}\right)$ & $\rho_{\mathrm{yx} 1}=0,332$ & \multirow{4}{*}{$68,4 \%$} \\
\hline General Interior $\left(\mathrm{X}_{2}\right)$ & $\rho_{\mathrm{yx} 2}=0,268$ & \\
\hline Store Layout $\left(\mathrm{X}_{3}\right)$ & $\rho_{\mathrm{yx} 3}=0,231$ & \\
\hline Interior Display $\left(\mathrm{X}_{4}\right)$ & $\rho_{\mathrm{yx} 4}=0,139$ & \\
\hline
\end{tabular}

Sumber : Hasil Penelitian, diolah (2018)

berikut:

Dengan memperhatikan tabel di atas, maka diperoleh persamaan jalur sebagai

$Y=0,332 X_{1}+0,268 X_{2}+0,231 X_{3}+0,139 X_{4}+\varepsilon_{1}$

Berdasarkan persamaan tersebut dapat diuraikan sebagai berikut:

Koefisien $\mathrm{X}_{1}\left(\rho_{\mathrm{yx} 1}\right)=0.332$. Ini menunjukan bahwa variabel exterior bernilai positif sehingga dapat dikatakan bahwa semakin baik exterior maka semakin tinggi pula minat beli konsumennya pada perusahaan tersebut. Koefisien jalur sebesar 0.332 berarti jika variabel exterior pada Sejiwa Coffee meningkat sebesar satu satuan, maka akan meningkatkan juga pertimbangan terhadap exterior dalam minat beli konsumen sebesar 0.332

Koefisien $\mathrm{X}_{2}\left(\rho_{\mathrm{yx} 2}\right)=0.268$. Ini menunjukan bahwa variabel General Interior bernilai positif sehingga dapat dikatakan bahwa semakin baik exterior maka semakin tinggi pula minat beli konsumennya pada perusahaan tersebut. Koefisien jalur sebesar 0.332 berarti jika variabel General Interior pada Sejiwa Coffee meningkat sebesar satu satuan, maka akan meningkatkan juga pertimbangan terhadap General Interior dalam minat beli konsumen sebesar 0.268

Koefisien $\mathrm{X}_{3}\left(\rho_{\mathrm{yx} 3}\right)=0.231$. Ini menunjukan bahwa variabel Store Layout bernilai positif sehingga dapat dikatakan bahwa semakin baik exterior maka semakin tinggi pula minat beli konsumennya pada perusahaan tersebut. Koefisien jalur sebesar 0.231 berarti jika variabel Store Layout pada Sejiwa Coffee meningkat sebesar satu satuan, maka akan meningkatkan juga pertimbangan terhadap Store Layout dalam minat beli konsumen sebesar 0.231

Koefisien $\mathrm{X}_{4}\left(\rho_{\mathrm{yx} 4}\right)=0.139$. Ini menunjukan bahwa variabel Store Layout bernilai positif sehingga dapat dikatakan bahwa semakin baik exterior maka semakin tinggi pula minat beli konsumennya pada perusahaan tersebut. Koefisien jalur sebesar 0.139 berarti jika variabel Store Layout pada Sejiwa Coffee meningkat sebesar satu satuan, maka akan meningkatkan juga pertimbangan terhadap Store Layout dalam minat beli konsumen sebesar 0.139

Dari persamaan diatas dapat diartikan bahwa nilai koefisien jalur variabel Exterior lebih besar dibandingkan koefisien jalur variabel lainnya artinya Exterior lebih menentukan (berpengaruh lebih besar) terhadap Minat Beli Konsumen dibandingkan General Interior, Store Layout dan Interior Display baik secara langsung maupun tak langsung.

Dari tabel diatas juga diperoleh total pengaruh variabel Exterior $\left(\mathrm{X}_{1}\right)$, General Interior $\left(\mathrm{X}_{2}\right)$, Store Layout $\left(\mathrm{X}_{3}\right)$, dan Interior layout $\left(\mathrm{X}_{4}\right)$ terhadap Minat Beli 
Konsumen adalah sebesar 0,684 atau sekitar 68,4\%, sedangkan pengaruh fak tor lainnya terhadap Minat Beli Konsumen ditunjukkan dengan nilai 1 - 0,684 =0,316 atau sekitar 31,6\%. Dengan kata lain, variabel Minat Beli Konsumen dapat dijelaskan sebesar $68,4 \%$ oleh variabel Exterior, General Interior, Store Layout, dan Interior Display sedangkan sisanya sebesar 31,6\% variabel Minat Beli Konsumen dapat dijelaskan oleh variabel lain yang tidak diteliti.

\section{Pengujian Secara Simultan (Uji F)}

$$
F=\frac{(n-k-1) \sum_{i=1}^{k} p_{y x i} r_{y x i}}{k\left(1-\sum_{i=1}^{k} p_{y x i} r_{y x i}\right)}
$$

Kriteria uji, Tolak Ho jika $\mathrm{F}$ hitung $\geq \mathrm{F}$ tabel, terima Ho dalam hal lainnya. Dimana $\mathrm{F}$ tabel diperoleh dari tabel distribusi $\mathrm{F}$ dengan $\alpha=5 \%$ dan derajat bebas $\mathrm{db}_{1}$ $=\mathrm{k}$, dan $\mathrm{db}_{2}=\mathrm{n}-\mathrm{k}-1$

Tabel 3. Pengujian SPSS Secara Simultan

\begin{tabular}{|l|l|l|l|l|}
\hline Hipotesis Alternatif & \multirow{2}{*}{ F hitung } & Db & F tabel & Kesimpulan \\
\cline { 1 - 1 } $\mathrm{X}_{1}, \mathrm{X}_{2}, \mathrm{X}_{3}$, dan $\mathrm{X}_{4}$ secara simultan & \multirow{2}{*}{214,148} & $\mathrm{db}_{1}=4$ & 2,395 & Signifikan \\
\cline { 3 - 4 } & & $\mathrm{db}_{2}=395$ & & \\
\hline
\end{tabular}

Sumber : Hasil Penelitian, diolah (2018)

Pada tabel diatas dapat kita ketahui bahwa hasil pengujian signifikan yang berarti Exterior $\left(\mathrm{X}_{1}\right)$, General Interior $\left(\mathrm{X}_{2}\right)$, Store Layout $\left(\mathrm{X}_{3}\right)$, dan Interior Display $\left(\mathrm{X}_{4}\right)$ secara simultan memiliki pengaruh signifikan terhadap Minat Beli Konsumen (Y) karena nilai $F$ hitung lebih besar dari $F$ tabel. Dengan demikian Hipotesis secara simultan dapat dite rima.

\section{Pengujian Hipotesis Secara Parsial (Uji T)}

$$
t_{i}=\frac{P_{y x i}}{\sqrt{\frac{\left(1-R^{2}\right) C R_{i i}}{n-k-1}}} \quad \mathrm{i}=1,2,3 \text {, dan } 4
$$

Kriteria uji:

Tolak Ho jika t hitung $>$ t table $\left(t_{\alpha ; n-k-1}\right)$

Hasil perhitungan dapat kita lihat pada table berikut ini:

Tabel 4. Hasil Uji T

\begin{tabular}{|l|l|l|l|l|l|}
\hline Hipotesis & t hitung & $\mathbf{d b}$ & $\mathbf{t}$ tabel & Keputusan & Kesimpulan \\
\hline$\rho_{\mathrm{y} x 1}=0$ & 9,077 & 395 & 1,96 & Ho ditolak & Signifikan \\
\hline$\rho_{\mathrm{yx} 2}=0$ & 5,514 & 395 & 1,96 & Ho ditolak & Signifikan \\
\hline$\rho_{\mathrm{yx} 3}=0$ & 4,832 & 395 & 1,96 & Ho ditolak & Signifikan \\
\hline$\rho_{\mathrm{yx} 4}=0$ & 3,213 & 395 & 1,96 & Ho ditolak & Signifikan \\
\hline
\end{tabular}

Sumber : Hasil Penelitian, diolah (2018) 
Dari tabel di atas dapat kita ketahui bahwa nilai t hitung untuk masing-masing variabel memiliki nilai lebih besar dari t tabel $(1,96)$ yaitu Exterior $\left(\mathrm{X}_{1}\right)$ sebesar 9,077, General Interior $\left(\mathrm{X}_{2}\right)$ sebesar 5,514, Store Layout $\left(\mathrm{X}_{3}\right)$ sebesar 4,832, dan Interior Display $\left(\mathrm{X}_{4}\right)$ sebesar 3,213 . Artinya secara parsial variabel-variabel dalam tersebut me mberikan pengaruh yang signifikan terhadap Minat Beli Konsumen (Y).

\section{Analisis Korelasi}

Tabel 5. Tabel Kolerasi

\begin{tabular}{|c|c|c|c|c|c|c|}
\hline & & Exterior & $\begin{array}{l}\text { General } \\
\text { Interior }\end{array}$ & $\begin{array}{c}\text { Store } \\
\text { Layout }\end{array}$ & $\begin{array}{l}\text { Interior } \\
\text { Display }\end{array}$ & $\begin{array}{l}\text { Minat Beli } \\
\text { Konsume n }\end{array}$ \\
\hline \multirow{3}{*}{ Exterior } & $\begin{array}{l}\text { Pearson } \\
\text { correlation }\end{array}$ & 1 & .623 & .520 & .509 & .690 \\
\hline & $\begin{array}{ll}\begin{array}{l}\text { Sig. } \\
\text { tailed })\end{array} & (2- \\
\end{array}$ & & .000 & .000 & .000 & .000 \\
\hline & $\mathrm{N}$ & 400 & 400 & 400 & 400 & 400 \\
\hline \multirow{3}{*}{$\begin{array}{l}\text { General } \\
\text { Interior }\end{array}$} & $\begin{array}{l}\text { Pearson } \\
\text { correlation }\end{array}$ & .623 & 1 & .754 & .684 & .745 \\
\hline & $\begin{array}{ll}\text { Sig. } \\
\text { tailed })\end{array}$ & .000 & & .000 & .000 & .000 \\
\hline & $\mathrm{N}$ & 400 & 400 & 400 & 400 & 400 \\
\hline \multirow{3}{*}{$\begin{array}{l}\text { Store } \\
\text { Layout }\end{array}$} & $\begin{array}{l}\text { Pearson } \\
\text { correlation }\end{array}$ & .520 & .754 & 1 & .725 & .707 \\
\hline & $\begin{array}{l}\text { Sig. } \\
\text { tailed })\end{array}$ & .000 & .000 & & .000 & .000 \\
\hline & $\mathrm{N}$ & 400 & 400 & 400 & 400 & 400 \\
\hline \multirow{3}{*}{$\begin{array}{l}\text { Display } \\
\text { Interior }\end{array}$} & $\begin{array}{l}\text { Pearson } \\
\text { correlation }\end{array}$ & .509 & .684 & .725 & 1 & .659 \\
\hline & $\begin{array}{l}\text { Sig. } \\
\text { tailed) }\end{array}$ & .000 & .000 & .000 & & .000 \\
\hline & $\mathrm{N}$ & 400 & 400 & 400 & 400 & 400 \\
\hline \multirow{3}{*}{$\begin{array}{l}\text { Minat Beli } \\
\text { Konsumen }\end{array}$} & $\begin{array}{l}\text { Pearson } \\
\text { correlation }\end{array}$ & .690 & .745 & .707 & .659 & 1 \\
\hline & $\begin{array}{l}\text { Sig. } \\
\text { tailed) }\end{array}$ & .000 & .000 & .000 & .000 & \\
\hline & $\mathrm{N}$ & 400 & 400 & 400 & 400 & 400 \\
\hline
\end{tabular}

Sumber : Hasil Penelitian, diolah (2018)

\begin{tabular}{|c|c|c|}
\hline Variabel & Koefisien Jalur & Total Pengaruh $\left(\mathbf{R}^{2}\right)$ \\
\hline Exterior $\left(\mathrm{X}_{1}\right)$ & $\rho_{\mathrm{yx} 1}=0,332$ & \multirow{4}{*}{$68,4 \%$} \\
\hline General Interior $\left(\mathrm{X}_{2}\right)$ & $\rho_{\mathrm{yx} 2}=0,268$ & \\
\hline Store Layout $\left(\mathrm{X}_{3}\right)$ & $\rho_{\mathrm{yx} 3}=0,231$ & \\
\hline Interior Display $\left(\mathrm{X}_{4}\right)$ & $\rho_{\mathrm{yx} 4}=0,139$ & \\
\hline
\end{tabular}




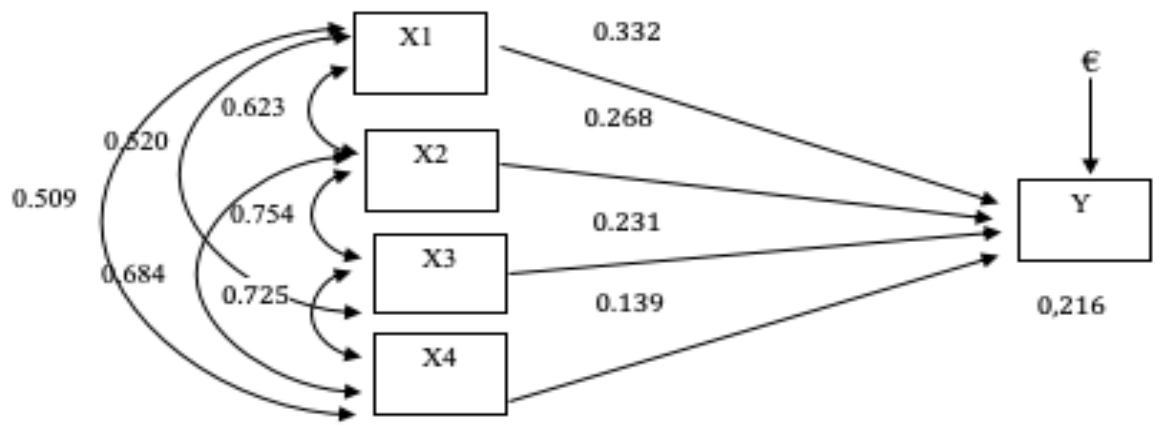

Pada gambar diagram diatas kita dapat melihat dari koefisien jalur exterior memberikan estimasi kontribusi terhadap minat beli konsumen sebesar 0.332 , general interior sebesar 0.268, store layout sebesar 0.231 dan interior display sebesar 0.139 yang artinya bahwa exterior lebih menentukan atau memberikan pengaruh lebih besar terhadap minat beli konsumennya dibandingkan general interior, store layout maupun interior display baik secara langsung maupun tidak langsung.

Adapun korelasi antar variabel bebasnya, sebagai berikut:

Korelasi antar exterior dan general interior

Berdasarkan hasil dari pengolahan SPSS, angka korelasi antar variabel exterior dan general interior sebesar 0,623. Untuk mengartikan angka tersebut dibutuhkan kriteria berikut:

$0-0,25 \quad:$ Korelasi sangat lemah (dianggap tidak ada)

$>0,25-0,5 \quad$ Korelasi cukup

$>0,5-0,75 \quad$ : Korelasi kuat

$>0,75-1 \quad$ :Korelasi sangat kuat

Korelasi sebesar 0,623 berarti hubungan antar variable exterior dan general interior kuat dan searah karena menghasilkan angka positif. Searah artinya jika exterior meningkat maka general interior juga meningkat. Korelasi antar dua variable tersebut juga signifikan karena $0,000<0,05$.

a. Korelasi antar exterior dan store layout

Berdasarkan hasil dari pengolahan SPSS, angka korelasi antar variabel exterior dan general interior sebesar 0,520. berarti hubungan antar variable exterior dan store layout kuat dan searah karena menghasilkan angka positif. Searah artinya jika exterior meningkat maka store layout juga meningkat. Korelasi antar dua variable tersebut juga signifikan karena $0,000<0,05$.

b. Korelasi antar exterior dan interior display

Berdasarkan hasil dari pengolahan SPSS, angka korelasi antar variabel exterior dan interior display sebesar 0,509. berarti hubungan antar variable exterior dan interior display kuat dan searah karena menghasilkan angka positif. Searah artinya jika exterior meningkat maka interior display juga meningkat. Korelasi antar dua variable tersebut juga signifikan karena $0,000<0,05$.

c. Korelasi antar general interior dan store layout

Berdasarkan hasil dari pengolahan SPSS, angka korelasi antar variabel general interior dan store layout sebesar 0,754. berarti hubungan antar variable general interior dan store layout kuat dan searah karena menghasilkan angka positif. 
Searah artinya jika general interior meningkat maka store layout juga meningkat. Korelasi antar dua variable tersebut juga signifikan karena $0,000<0,05$.

d. Korelasi antar general interior dan interior display

Berdasarkan hasil dari pengolahan SPSS, angka korelasi antar variabel general interior dan interior display sebesar 0,684. berarti hubungan antar variable general interior dan interior display kuat dan searah karena menghasilkan angka positif. Searah artinya jika general interior meningkat maka interior display juga meningkat. Korelasi antar dua variable tersebut juga signifikan karena $0,000<0,05$.

e. Korelasi antar store layout dan interior display

Berdasarkan hasil dari pengolahan SPSS, angka korelasi antar variabel store layout dan interior display sebesar 0,725. berarti hubungan antar variable store layout dan interior display kuat dan searah karena menghasilkan angka positif. Searah artinya jika store layout meningkat maka interior display juga meningkat. Korelasi antar dua variable tersebut juga signifikan karena $0,000<0,05$.

Total Pengaruh Langsung Maupun Tidak Langsung Exterior $\left(\mathrm{X}_{1}\right)$, General Interior $\left(\mathbf{X}_{2}\right)$, Store Layout $\left(\mathbf{X}_{3}\right)$, dan Interior Dis play $\left(\mathbf{X}_{4}\right)$ Terhadap Minat Beli Konsume n (Y)

Tabel 6. Pengaruh Langs ung Dan Tidak Langs ung Exterior Terhadap Minat Beli Kons umen

\begin{tabular}{|l|l|l|}
\hline $\begin{array}{l}\text { Pengaruh langsung dan tidak } \\
\text { langsung }\end{array}$ & Besar kontribusi \\
\hline $\mathrm{X} 1$ langsung & $\rho_{\mathrm{yx} 1} \rho_{\mathrm{yx} 1}$ & $7,20 \%$ \\
\hline $\mathrm{X} 1$ melalui $\mathrm{X} 2$ & $\rho_{\mathrm{yx} 1} \mathrm{r}_{\mathrm{x} 1 \mathrm{x} 2} \rho_{\mathrm{yx} 2}$ & $5,55 \%$ \\
\hline $\mathrm{X} 1$ melalui $\mathrm{X} 3$ & $\rho_{\mathrm{yx} 1} \mathrm{r}_{\mathrm{x} 1 \mathrm{x} 3} \rho_{\mathrm{yx} 3}$ & $4,68 \%$ \\
\hline $\mathrm{X} 1$ melalui X4 & $\rho_{\mathrm{yx} 1} \mathrm{r}_{\mathrm{x} 1 \mathrm{x} 4} \rho_{\mathrm{yx} 4}$ & $2,56 \%$ \\
\hline \multicolumn{2}{|l|}{ Total pengaruh X1 terhadap $\mathrm{Y}$} & $22,90 \%$ \\
\hline
\end{tabular}

Sumber : Hasil Penelitian, diolah (2018)

Dari tabel diatas dapat kita ketahui bahwa total pengaruh yang diberikan variabel Exterior $\left(\mathrm{X}_{1}\right)$ terhadap variabel Minat Beli Konsumen adalah sebesar 22,90\%. Pengaruh langsung sebesar 11,01\% dan tidak langsung sebesar 11,9\%

Tabel 7. Pengaruh Langs ung dan Tidak Langsung Gene ral Inte rior Terhadap Minat Beli Kons umen

\begin{tabular}{|l|l|l|}
\hline \multicolumn{2}{|c|}{$\begin{array}{c}\text { Pengaruh Langsung dan Tidak } \\
\text { Langsung }\end{array}$} & Besar kontribusi \\
\hline $\mathrm{X} 2$ langsung & $\rho_{\mathrm{yx} 2} \rho_{\mathrm{y} x 2}$ & $7,20 \%$ \\
\hline $\mathrm{X} 2$ melalui $\mathrm{X} 1$ & $\rho_{\mathrm{yx} 2} \mathrm{r}_{\mathrm{x} 1 \mathrm{x} 2} \rho_{\mathrm{yx} 1}$ & $5,55 \%$ \\
\hline $\mathrm{X} 2$ melalui $\mathrm{X} 3$ & $\rho_{\mathrm{yx} 2} \mathrm{r}_{\mathrm{x} 2 \mathrm{x} 3} \rho_{\mathrm{yx} 3}$ & $4,68 \%$ \\
\hline $\mathrm{X} 2$ melalui $\mathrm{X} 4$ & $\rho_{\mathrm{yx} 2} \mathrm{r}_{\mathrm{x} 2 \mathrm{x} 4} \rho_{\mathrm{yx} 4}$ & $2,56 \%$ \\
\hline \multicolumn{2}{|l|}{ Total pengaruh X2 terhadap Y } & $19,99 \%$ \\
\hline
\end{tabular}

Sumber : Hasil Penelitian, diolah (2018) 
Dari tabel di atas dapat kita ketahui bahwa total pengaruh yang diberikan variabel General Interior $\left(\mathrm{X}_{2}\right)$ terhadap variabel Minat Beli Konsumen adalah sebesar 19,99\%. Pengaruh langsung sebesar 7,20\% dan tidak langsung sebesar 12,79\%

Tabel 8. Penga ruh Langs ung dan Tidak Langsung Store Layout Terhadap Minat Beli Kons umen

\begin{tabular}{|l|l|l|}
\hline \multicolumn{2}{|l|}{$\begin{array}{l}\text { Pengaruh langsung dan tidak } \\
\text { langsung }\end{array}$} & Besar kontribusi \\
\hline $\mathrm{X} 3$ langsung & $\rho_{\mathrm{yx} 3} \rho_{\mathrm{yx} 3}$ & $5,36 \%$ \\
\hline $\mathrm{X} 3$ melalui $\mathrm{X} 1$ & $\rho_{\mathrm{yx} 3} r_{\mathrm{x} 1 \times 3} \rho_{\mathrm{y} x 1}$ & $3,99 \%$ \\
\hline $\mathrm{X} 3$ melalui X2 & $\rho_{\mathrm{yx} 3} r_{\mathrm{x} 2 \times 3} \rho_{\mathrm{y} x}$ & $4,68 \%$ \\
\hline $\mathrm{X} 3$ melalui X4 & $\rho_{\mathrm{yx} 3} r_{\mathrm{x} 3 \mathrm{x} 4} \rho_{\mathrm{yx} 4}$ & $2,34 \%$ \\
\hline Total pengaruh X3 terhadap Y & $16,37 \%$ \\
\hline
\end{tabular}

Sumber : Hasil Penelitian, diolah (2018)

Dari tabel di atas dapat kita ketahui bahwa total pengaruh yang diberikan variabel Store Layout $\left(\mathrm{X}_{3}\right)$ terhadap variabel Minat Beli Konsumen adalah sebesar 16,37\%. Pengaruh langsung sebesar 5,36\% dan tidak langsung sebesar 11,01\%

Tabe19. Pengaruh Langsung Dan Tidak Langsung Interior Display Terhadap Minat Beli Konsumen

\begin{tabular}{|l|l|l|}
\hline $\begin{array}{l}\text { Pengaruh langsung dan tidak } \\
\text { langsung }\end{array}$ & Besar kontribusi \\
\hline $\mathrm{X} 4$ langsung & $\rho_{\mathrm{y} x 4} \rho_{\mathrm{y} x 4}$ & $1,94 \%$ \\
\hline $\mathrm{X} 4$ melalui $\mathrm{X} 1$ & $\rho_{\mathrm{y} x} \mathrm{r}_{\mathrm{x} 1 \mathrm{x} 4} \rho_{\mathrm{yx} 1}$ & $2,35 \%$ \\
\hline $\mathrm{X} 4$ melalui $\mathrm{X} 2$ & $\rho_{\mathrm{y} x 4} \mathrm{r}_{\mathrm{x} 2 \mathrm{x} 4} \rho_{\mathrm{yx} 2}$ & $2,56 \%$ \\
\hline $\mathrm{X} 4$ melalui X3 & $\rho_{\mathrm{yx} 4} \mathrm{r}_{\mathrm{x} 3 \mathrm{x} 4} \rho_{\mathrm{yx} 3}$ & $2,34 \%$ \\
\hline Total pengaruh X4 terhadap Y & $9,19 \%$ \\
\hline
\end{tabular}

Sumber : Hasil Penelitian, diolah (2018)

Dari tabel diatas dapat kita ketahui bahwa total pengaruh yang diberikan variabel Interior Display $\left(\mathrm{X}_{4}\right)$ terhadap variabel Minat Beli Konsumen adalah sebesar 9,19\%. Pengaruh langsung sebesar $1,94 \%$ dan tidak langsung sebesar 7,25\%

\section{Pembahasan}

\section{Pembahasan Analisis Deskriptif Store Atmosphere}

Untuk perhitungan masing-masing sub-variabel, dari persepsi responden General Interior menunjukkan skor tertinggi yaitu sebesar 21547 atau 82,9\% dari skor ideal yaitu 26000. Dengan demikian tanggapan responden mengenai general interior memiliki kategori yang baik. Hal tersebut didukung dengan musik di Sejiwa Coffee membuat suasana hati pengunjung menjadi baik, peletakan peralatan di Sejiwa Coffee menciptakan estetika pada cafe dan tekstur dinding yang dimiliki Sejiwa Coffee terkesan menarik.

Lalu disusul oleh Interior Display menunjukkan skor persepsi responden sebesar 8068 atau 80,7\% dari skor ideal yaitu 10000. Dengan demikian tanggapan responden mengenai Interior Display memiliki kategori yang baik. Hal tersebut didukung dengan etalase di Sejiwa Coffee yang membuat pengunjung ingin mencoba, 
display yang di tampilkan Sejiwa Coffee sesuai dengan tema dan tanda kasir Sejiwa Coffee dapat terlihat jelas.

Kemudian Store Layout menunjukkan skor persepsi responden sebesar 9521 atau $79,3 \%$ dari skor ideal yaitu 12000. Dengan demikian tanggapan responden mengenai store layout memiliki kategori yang baik. Hal tersebut didukung dengan klasifikasi produk yang dapat memudahkan pengunjung untuk memilih menu, petunjuk Sejiwa Coffee memudahkan pengunjung untuk mengikuti alur pola di dalam café dan penataan menu makanan Sejiwa Coffee terlihat menarik.

Terakhir, Exterior sebesar 12478 atau 78,0\% dari skor ideal yaitu 16000. Dengan demikian tanggapan responden mengenai eksterior memiliki kategori yang baik. Hal tersebut didukung dengan bagian bangunan depan Sejiwa Coffee mencerminkan keunikan yang sesuai dengan citra cafe, isyarat kisaran harga Sejiwa Coffee dapat ditangkap oleh pengunjung dengan melihat lingkungan sekitar cafe dan isyarat kisaran tingkat pelayanan Sejiwa Coffee dapat ditangkap oleh pengunjung dengan melihat lingkungan sekitar cafe.

Store Atmosphere secara simultan menunjukkan skor persepsi responden sebesar 51614 atau 80,6\% dari skor ideal yaitu 64000. Dengan demikian tanggapan responden mengenai Store Atmosphere memiliki kategori yang baik. Dibandingkan dengan hasil penelitian terdahulu, Rizki \& Wardhana (2016) nilai Store Atmosphere yang peroleh Café Bene Bandung terbilang baik dengan hasil 72,2\% yang berarti tanggapan responden mengenai kedua café tersebut Sejiwa Coffe lebih unggul dalam penerapan Store Atmosphere.

\section{Pembahasan Analisis Deskriptif Minat Beli Konsumen}

Begitupun juga dengan Minat Beli Konsumen pada Sejiwa Coffee menunjukkan nilai yang diperoleh 7725 atau 77,3\% dari skor ideal yaitu 10000. Dengan demikian tanggapan responden mengenai minat beli konsumen memiliki kategori yang baik. Hal tersebut didukung dengan ketertarikan pengunjung untuk mencari informasi yang lebih tentang Sejiwa Coffee, keinginan pengunjung untuk memiliki pengalaman mencoba produk Sejiwa coffee dan ketertarikan pengunjung untuk mengkonsumsi layanan Sejiwa Coffee. Dibandingkan dengan hasil penelitian terdahulu, Rizki \& Wardhana (2016) nilai Minat Beli Konsumen yang peroleh Café Bene Bandung terbilang baik dengan hasil 74,4\% yang berarti tanggapan responden mengenai kedua café tersebut Café Bene Bandung lebih unggul dalam menarik minat beli konsumen.

\section{Pembahasan Pengaruh Store Atmosphere Secara Simultan}

Exterior $\left(\mathrm{X}_{1}\right)$, General Interior $\left(\mathrm{X}_{2}\right)$, Store Layout $\left(\mathrm{X}_{3}\right)$, dan Interior Display $\left(\mathrm{X}_{4}\right)$ secara simultan memiliki pengaruh positif dan signifikan terhadap Minat Beli Konsumen (Y) karena nilai F hitung $(214,148)$ lebih besar dari F table $(2,395)$. Total pengaruh sebesar 68,4\%. Dengan demikian Hipotesis secara simultan dapat diterima. Sesuai dengan hasil penelitian terdahulu, Rizki \& Wardhana (2016) store atmosphere yang dimiliki Café Bene secara simultan berpengaruh positif dan signifikan terhadap minat beli konsumen. 


\section{Pembahasan Pengaruh Store Atmosphere Secara Parsial}

Store atmosphere memiliki empat sub-variabel yang terdiri dari exterior, general interior, store layout dan interior display. Nilai t hitung untuk masing-masing variabel memiliki nilai lebih besar dari t tabel $(1,96)$ yaitu Exterior $\left(\mathrm{X}_{1}\right)$ sebesar 9,077, General Interior $\left(\mathrm{X}_{2}\right)$ sebesar 5,514, Store Layout $\left(\mathrm{X}_{3}\right)$ sebesar 4,832, dan Interior Display $\left(\mathrm{X}_{4}\right)$ sebesar 3,213. Artinya secara parsial variabel-variabel dalam tersebut memberikan pengaruh yang positif dan signifikan terhadap Minat Beli Konsumen (Y). Total pengaruh dari masing- masing variable yaitu, Exterior memiliki pengaruh yang paling besar terhadap minat beli konsumen yaitu sebesar 22,90\%. Hal tersebut didukung oleh tampak bagian depan Sejiwa Coffee yang unik, tampilan pajangan Sejiwa Coffee yang menarik, papan nama atau logo yang jelas, pintu yang memudahkan konsumen keluar masuk toko. Interior display memiliki total pengaruh yang paling kecil yaitu sebesar 9,19\%. Hal itu terjadi karena tanda petunjuk toilet Sejiwa Coffee yang kurang jelas, lukisan dinding Sejiwa Coffee yang kurang menarik. Sedangkan general interior memiliki total pengaruh sebesar $19,99 \%$ dan store layout sebesar 16,37\% terhadap minat beli konsumen. Apabila jika total pengaruh dari masing - masing sub-variabel store atmosphere tersebut dijumlahkan maka akan menghasilkan total pengaruh sebesar $68,4 \%\left(\mathrm{R}^{2}\right)$. Dengan demikian maka Hipotesis secara parsial dapat diterima. Sesuai dengan hasil penelitian terdahulu, Rizki \& Wardhana (2016) store atmosphere yang terdiri dari Exterior, General Interior, Store Layout dan Interior Display yang dimiliki Café Bene secara parsial berpengaruh positif dan signifikan terhadap minat beli konsumen.

\section{KESIMPULAN DAN SARAN \\ Kesimpulan}

Berdasarkan hasil penelitian dan analisa yang telah dilakukan, didapatkan beberapa kesimpulan yang memberikan jawaban terhadap rumusan masalah yaitu Store Atmosphere pada Sejiwa coffee memiliki kategori yang baik, yaitu sebesar 80,6\%. Minat Beli Konsumen pada Sejiwa coffee memiliki kategori yang baik yaitu sebesar $77,3 \%$.

Secara simultan store atmosphere memiliki pengaruh positif dan signifikan terhadap minat beli konsumen pada Sejiwa Coffee, karena nilai F hitung $(214,148)$ lebih besar dari F table (2,395). Dengan demikian Hipotesis secara simultan dapat diterima.

Secara parsial store atmosphere memiliki pengaruh positif dan signifikan terhadap minat beli konsumen pada Sejiwa Coffee, Karena nilai t hitung untuk masingmasing variabel memiliki nilai lebih besar dari t tabel $(1,96)$ yaitu Exterior $\left(\mathrm{X}_{1}\right)$ sebesar 9,077, General Interior $\left(X_{2}\right)$ sebesar 5,514, Store Layout $\left(X_{3}\right)$ sebesar 4,832, dan Interior Display $\left(X_{4}\right)$ sebesar 3,213. Dengan demikian Hipotesis secara parsial dapat diterima.

\section{Saran}

1. Saran Teoritis

Untuk penelitian selanjutnya diharapkan peneliti menambahkan variable lain yang dapat mempengaruhi minat beli konsumen pada Sejiwa Coffee karena 31,6\% 
minat beli konsumen pada Sejiwa Coffee dipengaruhi faktor lain diluar store atmosphere.

2. Saran Praktis

Berdasarkan hasil dari penelitian ini Exterior memiliki pengaruh yang paling besar terhadap minat beli konsumen dibandingkan dengan sub-variable store atmosphere lainnya, maka Sejiwa Coffee perlu adanya perbaikan untuk jenis pintu yang digunakan untuk memudahkan pengunjung masuk dan keluar café, eksterior bangunan yang jelas dari kejauhan dan menyediakan tempat parkir yang luas untuk pengunjungnya.

Dari sub variabel general interior sebaiknya Sejiwa Coffee melakukan perbaikan untuk penentuan desain lantai yang lebih menarik, aroma café memberikan kenyamanan untuk pengunjung dan seharusnya lebih menonjolkan aroma kopi karena sebagai ciri khas sebuah coffeeshop serta kerapihan dari penampilan karyawannya.

Dari sub variabel store layout sebaiknya Sejiwa Coffee melakukan perbaikan untuk layout yang lebih membuat pengunjung nyaman, penataan menu makanan yang lebih rapi dan lebar jarak yang membuat pengunjung nyaman untuk bergerak.

Dari sub variabel Interior Display sebaiknya Sejiwa Coffee melakukan perbaikan untuk display yang menyesuaikan tema hari - hari peringatan (valentine, hari kemerdekaan dan konsep lainnya), tanda petunjuk toilet yang lebih jelas dan lukisan dinding yang tidak membosankan.

\section{DAFTAR PUSTAKA}

Berman dan Evans, 2010. "Retail Management". 12th Edition. Jakarta; Pearson.Leivy \& Weitz. 2012. Retailing Management Information Center. New York: McGraw-Hill Higher Education.

Schiffman dan Kanuk. 2008. Perilaku Konsumen. Edisi 7. Jakarta: Indeks

Schiffman, L.G. dan Kanuk. 2012. Consumer Behaviour. USA : New Jersey Prentice Hall.

Suhartanto, Dwi, Tjetjep Djatnika, Ruhadi \& Ni Nyoman Triyuni. 2017. Ritel. Bandung: Alfabeta.

Katarika \& Syahputra. 2017. Pengaruh Store Atmosphere terhadap Keputusan pembelian pada Coffee Shop di Bandung. Jurnal Ecodemica, Vol.1 No. 2

Putra, Bayu Dewangga \& Wijaksana, Tri Indra. 2017. Pengaruh Store Atmosphere Terhadap Minat Beli Konsumen pada Armor Kopi Bandung. E- Proceeding of Management: Vol.4, No.1 